\title{
Performance Measurement And Management in the Upstream Oil And Gas Sector
}

\author{
Musa Yelwa Abubakar ${ }^{1}$, Sunusi Sa'ad Ahmad ${ }^{2}$, Nasiru Abdulsalam Kaoje ${ }^{3}$, \\ Mohammed Abdulazeez ${ }^{4}$ \\ ${ }^{1}$ Departmen Of Accounting, Usmanu Danfodiyo University Sokoto, Nigeria \\ ${ }^{2}$ Departmen Of Accounting, Usmanu Danfodiyo University Sokoto, Nigeria \\ ${ }^{3}$ Departmen Of Accounting, Usmanu Danfodiyo University Sokoto, Nigeria \\ ${ }^{4}$ department Of Accountancy, School Of Management Studies, Kano State Polytechnic, Nigeria
}

\begin{abstract}
The concept of performance measurement and management (PMM) has gained a wide publicity among the International Oil and Gas Companies. Recent years have witnessed transformation from traditional financial PMM to a more sophisticated approach that encompasses both financial and non-financial aspects of a business. This paper is aimed at measuring the financial performance of International Oil Companies (IOCs) and assessing whether the performance is being improved over the three years covered. Data Envelopment Analysis (DEA) is used to develop a model using principles of Linear Programming, in measuring the performance and assessing whether such performance is being managed. Total assets and running cost are used as an input while three financial ratios and an oil reserve ratio are used as output to determine whether the inputs are best utilised in generating the outputs and whether the outputs generated are worth the input. The paper reveals that, oil companies measure their performance in order to reveal areas that need attention, but most of the oil companies in the sample have unfavourable performance. However, no evidence that their performance has been improved (managed) over the period covered.
\end{abstract}

Keywords : Performance Measurement, Performance Management, Oil and Gas Industry

\section{Introduction}

Oil industry is vital to world economy and is the mainstay of many economies. Performance measurement and management in the industry is critical to enhancing the industry's performance and world's economy as a whole.

Within the International Oil and Gas industry, the existence and importance of a wider set of stakeholders has long been acknowledged, but the need for oil companies to achieve their congruent objectives which substantially depends on how effective they measure and manage their performance (Pock, Westlund, \& Fahrni, 2004). Congruent objectives cannot be achieved without proper management as each party to a company may strive to satisfy its own goal. The performance of these companies is critical not only to the companies themselves, but to the nations' economic growth, especially oil dependent countries like Nigeria. Emphasis is normally placed on what happens in the oil and gas industry because the major tax payer in most oil dependent economies is the oil industry; therefore the need to ensure the companies operating within the industry do perform to various stakeholders' expectations for sustainable development of both the companies and countries. Assessment of performance of these companies can be looked at from different perspectives which can either be financial or non-financial. However, the best practice requires that companies should perform both financially and non-financially (Mayston 2005; Pollit 1986). For example, there is thus a difference of opinion, some scholars argue the government should provide a leading edge on issues of performance measurement in the public sector for private sector to follow (Lapsey and Mitchell, 1996), others argue that the performance measurement systems "measure too many things including the wrong things" (Atkinson et al., 2007, p. 26). Because of pressures on private sector organisations to meet the information needs of a large number of stakeholders (Santos, et al., 2007).

Consequently, there are several measurement tools that measure both financial and non-financial performance of a company amongst which are Balanced Scorecard BSC, Customer profitability analysis, Benchmarking, Ratio analysis and Data Envelopment Analysis (DEA). The most widely used measure and manager of performance is the Balanced Scorecard as it measures all dimensions of business' performance and provides a basic framework for management of the performance (Anthes, 2003). The BSC is popular as it measures not only organizational performance as a whole but individual employee's performance as such it is very helpful in designing an incentive scheme in an organization.

Upstream oil and gas operation refers to those activities that take place from exploration of oil and gas up to the production of crude oil and gas (Wright \& Gallun, 2008). These activities encompass Geological and Geophysical studies (G\&G), drilling and lifting of oil and lifting of oil and natural gas. IOCs operating in the upstream do so with the aim of meeting their objectives, which include profit maximization, wealth 
maximization or occupying larger market share. As a result, they must keep track of their activities to ensure that the desired goal is achieved. The way by which a track of these activities is made falls within the scope of performance measurement and management (Crane, 2007).

\section{Literature Review}

There has been an extensive debate on the exact business measure of performance (Santos, et al., 2007). Though several researches have been conducted in the field, but lack of universally accepted measures of performance hinders development in the research area (Marr \& Schiuma, 2003). Scholars from many disciplines such as management accounting, human resource management, organization and consumer behaviour and management information system consider performance measurement as more related to their field than other disciplines, and as such, apply performance measurement tools that are suitable to their profession in assessing business performance. Consequently, this undermines the real measure of business performance. A case in point is the financial reporting system of companies which is statutorily required by law and standards do not provide reliable information as to performance of a particular company (Kriestensen \& Westlund, 2004), neither do they provide early warning when the company experiences difficulties.

\subsection{Concept of Performance Measurement}

Performance measurement has traditionally been identified to encompass a measure that serves as an operational control and derived from statutory financial reporting (Kuwaiti, 2004). Some Authors (Gomes et al., 2011) are of the view that the prime objective of performance measurement is to aid planning and ensure that operations are carried out in line with organizational objectives. In modern day time, performance measurement goes beyond simply ascertaining business position for external reporting purpose, but involves several measures that translate the prospects of business (both internally and externally) into its ability to continue as a going concern. Thus, the traditional measurement system encounters serious setback by its limitations to measure past, present and future trends as well as company's performance due to its sided measure (Bala \& Cook, 2003).

In view of this, Bala and Cook (2003) suggest the use of other measurement tools including Data Envelopment Analysis (DEA) which in addition to comprehensive measurement, also benchmarks two or more departments, sections or organizations so as to enable organization compare its performance vis-a-vis other organizations. This is supported by Dervitsiotis (2004) research in which he concludes that the traditional measurement system used by management for management decision making, needs complete overhauling as they only measure the past and current business condition not minding the degree of appropriateness of various measures that suit business's changing environment.

Majority of challenges faced by managers, employees and other stakeholders including potential investors lie in the heart of poor measurement system which normally affects expectation and outcomes (Dervitsiotis, 2004). This clearly indicates that there is no constant measure for all business circumstances, but measures should always be dynamic as to conform to a particular situation. Therefore, for sustainability, businesses need to perform to the expectation of their customers, suppliers and other stakeholders. In fact, for a business to perform well, it requires satisfying the needs of its customers more than its competitors (Kottler, 1984) cited in Neely et al. (2005). Hence, the concept of performance itself in this regard means the extent to which a business operates efficiently and effectively.

In the context of this paper (the oil and gas industry) privately owned IOCs normally apply different performance measurement and management tools over and above the state owned companies (National Oil Companies) as such, perform better than NOCs (Wolf, 2009). That is to say, performance itself, to some extent depends on ownership structure and that IOCs outperform NOCs because of differing compliance with performance measurement and management principles. However, the state-owned oil companies do perform better that the privately-owned oil companies in relation to the production cost per barrel of crude oil produced (Ahmad and Kouhy, 2014).

\subsection{Financial Performance Measurement}

Apart from the use of balanced scorecard as performance measurement and management tool, a number of other measures exist. One prominent tool is that of ratio analysis though focuses mainly on financial measures, but measures non-financial aspects also. Ratios are mostly used to measure the overall performance of an organization rather than individual employee, section or departmental as obtained under scorecard. Ratios calculated from the financial statements help assess the financial well-being of the overall organization. Information about the financial position of each organization is important for company's management decisions, but by themselves (ratios) are inadequate for certain decisions because they do not describe the overall company's business (Crane, 2007). 


\subsection{Oil and Gas Companies Specific Ratios}

Oil and gas industry has its own peculiarities different from other industries in that it has different accounting system as such different terminologies. Some accounting concepts (such as Matching Concept) applicable to other industries are not applicable to oil and gas industries owing to its characteristics, because expenditures cannot be matched to resulting reserves in a particular accounting period due to length of time taken from exploration to production (Wright \& Gallun, 2008) and the divergent views on whether to apply a successful efforts method or a full-cost method (Ahmad, 2012). Apart from the usual financial ratios applicable to almost all the industries, oil and gas industry has specific ratio very much relevant to any company that operates within the industry. Most of these ratios are non-financial in nature, but tell more than financial ratios in relation to survival of any oil company. Some of these ratios are Reserve to Production Ratio, Reserve Replacement Ratio and Finding Cost per Barrel of Oil.

\subsection{Population and Sample of the Study}

\section{Research Design}

This paper on International Oil Companies who are members of International Petroleum Industry Environmental Conservation Association (IPIECA) and operate upstream activities. As at August 2015, there are fifty members (50) of IPIECA consisting of 34 oil companies and 16 associations (IPIECA, 2012). The thirty four member companies of IPIECA who are oil companies therefore, constitute the population of the study. Ten out of the 34 have been selected as the sample size. The sample has been selected based on the following criteria:

i) Only companies that operate internationally are included in the sample.

ii) Only companies established as limited liability companies are included in the sample, as such, National oil corporations (which are public corporations) are exempted.

iii) Ten out of the total companies are randomly selected.

Going by the nature of the scope of this paper which is financial performance measurement and management in the International Oil Companies (IOCs), the variables examined are those that reveal the financial performance of the companies represented by the sample. These financial measures are contained in the Annual Reports of these organizations as such data related to this work were solely obtained from the annual reports and accounts of the sampled companies. Some specific accounting measures of financial performance considered in this paper consist of profitability, liquidity and market ratios.

Traditional financial performance measurement system which expresses performance in the form of ratios is used and this was calculated for each variable in each company for three financial years; 2009, 2010 and 2011. The results derived from raios were used as inputs in the Data Envelopment Analysis (DEA) model to determine the performance of each company in each year.

DEA is a tool most appropriate for financial performance measures as it computes a comparative ratio of average outputs to average inputs for each decision-making unit (DMU) using linear programming (Avkiran, 2011). It uses a scale of $0-1$ as decision making criteria with 1 representing efficient performance 0 worst performance. Scores between 0 and 1are interpreted based on the threshold determined.

Although, there are many different formulations of DEA models, this paper opted to use CCR (Charnes, Cooper \& Rhodes, 1978) basic DEA model, because it involves simple basic assumptions and it is the most widely used. Moreover, all other DEA models have been built on the basis of this original CCR. The model is mathematically expressed as follows:

$$
\begin{aligned}
& \min _{\lambda=} \theta=\theta^{*} \\
& \text { Subject to } \\
& \theta x_{0}-\sum_{j=1}^{n Z} \lambda_{j} x_{i} \geq 0 \\
& y_{0}-\sum_{j=1}^{n g} \lambda_{j} y_{i} \leq 0 \\
& \theta_{v} \lambda \geq 0 \\
& \text { Where } \\
& \theta=\text { Performance index } \\
& \lambda_{j}=\text { Intensity variable } \\
& x_{0}=\text { Production inputs of the focused decision making units } \\
& x_{i}=\text { Production inputs of all DMUs in the sample }
\end{aligned}
$$


$Y_{0}=$ Production output of the focused DMU

Yh: Production outputs of all DMUs in the sample

This very version of the model is referred to as the input oriented model, for the performance index is incorporated in the LP modelling as the coefficient of production input $(x)$. The model is formulated in such a manner that it benchmarks all DMUs included in the modeling against identified best practice or practices with a view to computing their performance indices.

This study particularly adopted the formulation of CCR for developing a model to enable the computation and evaluation of the financial performance indexes of multinational oil and gas companies in the sample. Therefore, based on the original CCR model in 1 above, the following DEA model is specified, in a piece-wise format (see Cooper et al., 2004).

$$
\begin{aligned}
& \min _{2, \theta} \theta=\text { FPI } \\
& \text { Subject to: } \\
& \theta x 1_{0}-\sum_{j=1}^{g} \lambda_{j} x 1_{i} \geq 0 \\
& \theta x 2_{0}-\sum_{j=1}^{n} \lambda_{j} x 2_{i} \geq 0 \\
& y 1_{0}-\sum_{j=1}^{n} \lambda_{j} y 1_{i} \leq 0 \\
& y 2_{o}-\sum_{j=1}^{n} \lambda_{j} y 2_{i} \leq 0 \\
& y 3_{0}-\sum_{j=1}^{n} \lambda_{j} y 3_{i} \leq 0 \\
& y 4_{0}-\sum_{j=1}^{n} \lambda_{j} y 4_{i} \leq 0 \\
& \theta_{0} \lambda \geq 0 \\
& x 2_{0}=\text { Total running cost of DMU } \\
& y 1_{0}=\text { Return on capital } \\
& y 2_{0}=\text { Acid test ratio } \\
& y 3_{0}=\text { Earnings per share } \\
& y 4_{0}=\text { Reserve replacement ratio (RRR) }
\end{aligned}
$$

Essential this input oriented envelopment model has been designed in such manner that it produces three important values, namely, overall financial performance index, DEA efficient capital inputs (i.e. x1 measured as total assets) and DEA efficient other running costs ( $\mathrm{x} 2$, which includes labour cost, cost of energy consumption and other related costs). The paper further processes these three important values by means of averaging and comparison in order to evaluate the financial performance of the companies in the sample

\section{Analysis and Results}

Based on the models developed above and the computation of different performance metrics in line with DEA model, the sampled companies appear to averagely have their performance indices as contained in table 4.1 below. The scale of the index ranges from 0 to 1 , with 0 signifying worst performance and 1 best performance.

Table 4.1Performance Indices

\begin{tabular}{|c|c|c|}
\hline COMPANY & YEAR & $\begin{array}{c}\text { PERFORMANCE INDEX } \\
\text { (PI) }\end{array}$ \\
\hline BRITISH PETROLEUM & 2009 & $\mathbf{0 . 1 1}$ \\
\hline BRITISH PETROLEUM & 2010 & $\mathbf{0 . 0 4}$ \\
\hline
\end{tabular}




\begin{tabular}{|l|l|l|}
\hline BRITISH PETROLEUM & 2011 & $\mathbf{0 . 1 1}$ \\
\hline SHELL PLC & 2009 & $\mathbf{0 . 2 4}$ \\
\hline SHELL PLC & 2010 & $\mathbf{0 . 1 2}$ \\
\hline SHELL PLC & 2011 & $\mathbf{0 . 1 5}$ \\
\hline CHEVRON & 2009 & $\mathbf{0 . 2 2}$ \\
\hline CHEVRON & 2010 & $\mathbf{0 . 3 4}$ \\
\hline CHEVRON & 2011 & $\mathbf{0 . 4 0}$ \\
\hline EXXON MOBIL & 2009 & $\mathbf{0 . 2 4}$ \\
\hline EXXON MOBIL & 2010 & $\mathbf{0 . 1 7}$ \\
\hline EXXON MOBIL & 2011 & $\mathbf{0 . 2 2}$ \\
\hline ENI LIMITED & 2009 & $\mathbf{0 . 1 8}$ \\
\hline ENI LIMITED & 2010 & $\mathbf{0 . 2 0}$ \\
\hline ENI LIMITED & 2011 & $\mathbf{0 . 1 7}$ \\
\hline CONOCOPHILIPS & 2009 & $\mathbf{0 . 2 0}$ \\
\hline CONOCOPHILIPS & 2010 & $\mathbf{0 . 3 4}$ \\
\hline CONOCOPHILIPS & 2011 & $\mathbf{0 . 3 8}$ \\
\hline TOTAL & 2009 & $\mathbf{0 . 2 3}$ \\
\hline TOTAL & 2010 & $\mathbf{0 . 2 6}$ \\
\hline TOTAL & 2011 & $\mathbf{0 . 2 4}$ \\
\hline BG GROUP & 2009 & $\mathbf{0 . 8 9}$ \\
\hline BG GROUP & 2010 & $\mathbf{1 . 0 0}$ \\
\hline BG GROUP & 2011 & $\mathbf{0 . 8 2}$ \\
\hline CNOOC & 2009 & $\mathbf{1 . 0 0}$ \\
\hline CNOOC & 2010 & $\mathbf{1 . 0 0}$ \\
\hline CNOOC & 2011 & $\mathbf{0 . 8 6}$ \\
\hline STATOIL & 2009 & $\mathbf{0 . 7 0}$ \\
\hline STATOIL & 2010 & $\mathbf{0 . 7 7}$ \\
\hline STATOIL & 2011 & $\mathbf{1 . 0 0}$ \\
\hline SOUICe: Generated & \\
\hline
\end{tabular}

Source: Generated by the Authors from DEA model output

Since the DEA model considers each company in each year as independent company, the ten companies in the sample now appear to be thirty. Therefore, the average performance of each company is taken to come out with single figure representing the average performance of each company over the three years. This resulted in the following table:

Table 4.2

\begin{tabular}{|l|c|}
\hline \multicolumn{2}{|c|}{ AVERAGE PERFORMANCE INDICES FOR YEARS 2009, 2010 \& 2011 } \\
\hline \multicolumn{1}{|c|}{ COMPANY } & AVERAGE PERFORMANCE INDEX \\
\hline BRITISH PETROLEUM (BP) & 0.085779072 \\
\hline SHELL & 0.167161818 \\
\hline CHEVRON & 0.320441318 \\
\hline EXXON MOBIL & 0.212304417 \\
\hline ENI & 0.181325405 \\
\hline CONOCOPHILIPS & 0.308494184 \\
\hline TOTAL & 0.244262287 \\
\hline BG GROUP & 0.90320202 \\
\hline CNOOC & 0.953811124 \\
\hline STATOIL & 0.824288901 \\
\hline
\end{tabular}

Source: Generated by the Authors from DEA model output

From the Table above, it can be seen that the lowest performing company is BP with 0.08 as its index, while the highest is CNOOC with 0.95. BG Group also is within the range of highest efficiency with 0.90, this shows that CNOOC has performed excellently over the three years covered by this research, followed by BG Group while BP and Shell have the lowest performance in relation to the sampled firms.

\subsection{Comparison of Actual Total Assets Cost with Efficient Cost}

The model developed considers total assets cost and running cost of the sampled companies to represent the input used to generate the outputs which are liquidity, profitability, market and oil reserves. From the DEA model run, the following table shows that each company could have minimized the total assets injected to achieve the current performance if it efficiently utilizes the assets. The table reveals the most efficient cost of assets that could have been committed based on current output which is a clear indicator of company's performance measurement and management. 
Table 4.3

\begin{tabular}{|l|r|r|r|}
\hline \multicolumn{4}{|c|}{ COMPARISON OF ACTUAL AND EFFICIENT TOTAL ASSETS COST } \\
\hline COMPANY & $\begin{array}{l}\text { VERAGE ACTUAL } \\
\text { X1 }\end{array}$ & $\begin{array}{l}\text { AVERAGE EFFICIENT } \\
\text { X1 }\end{array}$ & DIFFERENCE \\
\hline BRITISH PETROLEUM & 267129.3333 & 22792.94908 & 244336.3843 \\
\hline SHELL PLC & 319999.3333 & 52668.34242 & 267330.9909 \\
\hline CHEVRON & 186288 & 61036.81548 & 125251.1845 \\
\hline EXXON MOBIL & 288961.6667 & 60672.30514 & 228289.3615 \\
\hline ENI LIMITED & 172067.265 & 31136.81154 & 140930.4535 \\
\hline CONOCOPHILIPS & 154043.3333 & 47581.62801 & 106461.7053 \\
\hline TOTAL & 191063.2935 & 46675.03957 & 144388.2539 \\
\hline BG GROUP & 50361.43278 & 42864.46667 & 7496.966113 \\
\hline CNOOC & 45881.61879 & 43245.14788 & 2636.470917 \\
\hline STATOIL & 106648.2115 & 90317.05389 & 16331.15761 \\
\hline
\end{tabular}

Source: DEA model output generated by the Authors

The average figures for three years are used for each company, and the result shows that each company could have spent not up to what it actually spent if it employed performance measurement and management technique effectively. The difference column shows the amount that could have been saved under efficient operations as revealed by the DEA model output above.

\subsection{Comparison of Actual Running Cost with Efficient Cost}

From the DEA model run, the following table shows that each company could have minimized the total running cost (comprising of labour cost, energy consumption and other overheads) injected to achieve the current performance if it efficiently managed the costs. The table reveals the most efficient running cost that could have been expended based on current output, which is a clear indicator of company's performance measurement and management.

Table 4.4

\begin{tabular}{|l|l|r|r|r|}
\hline \multicolumn{5}{|l|}{ COMPARISON OF ACTUAL RUNNING COST WITH EFFICIENT COST } \\
\cline { 2 - 5 } & $\begin{array}{l}\text { AVERAGE } \\
\text { ACTUAL X2 }\end{array}$ & $\begin{array}{l}\text { AVERAGE } \\
\text { EFFICIENT X2 }\end{array}$ & \multicolumn{1}{|c|}{ DIFFERENCE } \\
\cline { 2 - 5 } & BRITISH & 294396.3333 & 7555.746347 & 286840.587 \\
PETROLEUM (BP) & 345248.6667 & 18031.95639 & 327216.7103 \\
\cline { 2 - 5 } & 177351 & 33158.17574 & 144192.8243 \\
\hline SHELL PLC & 339747.6667 & 26182.01042 & 13565.6562 \\
\hline CHEVRON & 118545.3631 & 11073.81372 & 159856.5494 \\
\hline EXXON MOBIL & 183312.6667 & 23455.96456 & 140769.9406 \\
\hline ENI LIMITED & 161255.6575 & 20485.71697 & 183.308642 \\
\hline CONOCOPHILIPS & 11585.34033 & 10402.03169 & 1901.13804 \\
\hline TOTAL & 15798.57067 & 13897.43263 & 15864.51874 \\
\hline BG GROUP & 65230.32439 & 49365.80565 & \\
\hline CNOOC & & & \\
\cline { 2 - 5 } & STATOIL & & & \\
\hline
\end{tabular}

Source: generated by the Authors from DEA output

As with total assets, the average figures for three years are also used for each company's running cost and the result shows that each company could have spent not up to what it actually spent if it employed performance measurement and management technique effectively. The difference column shows the amount that could have been saved under efficient operations as revealed by the DEA model run in form of linear programming.

\subsection{Comparison of Actual Total Input with Efficient Input}

The clear performance efficiency can be revealed by summation of actual input variables and comparing it with most efficient cost of input as revealed by DEA model. The following table difference in total of what would have been saved if performance is being managed effectively and efficiently.

Table 4.5

\begin{tabular}{|l|r|r|r|}
\hline \multicolumn{3}{|c|}{ COMPARISON OF ACTUAL TOTAL INPUT WITH EFFICIENT INPUT } \\
\hline COMPANY & $\begin{array}{c}\text { ACTUAL TOTAL } \\
\text { INPUT X1 X2 }\end{array}$ & $\begin{array}{c}\text { EFFICIENT TOTAL } \\
\text { INPUT X1 X2 }\end{array}$ & DIFFERENCE \\
\hline BRITISH PETROLEUM (BP) & 561525.667 & 30348.6954 & 531176.9712 \\
\hline SHELL PLC & 665248 & 70700.2988 & 594547.7012 \\
\hline CHEVRON & 363639 & 94194.9912 & 269444.0088 \\
\hline EXXON MOBIL & 628709.333 & 86854.3156 & 541855.0178 \\
\hline ENI LIMITED & 290612.628 & 42210.6253 & 248402.0029 \\
\hline
\end{tabular}


Performance Measurement And Management In The Upstream Oil And Gas Sector

\begin{tabular}{|l|r|r|r|}
\hline CONOCOPHILIPS & 337356 & 71037.5926 & 266318.4074 \\
\hline TOTAL & 352318.951 & 67160.7565 & 285158.1945 \\
\hline BG GROUP & 61946.7731 & 53266.4984 & 8680.274755 \\
\hline CNOOC & 61680.1895 & 57142.5805 & 4537.608957 \\
\hline STATOIL & 171878.536 & 139682.86 & 32195.67636 \\
\hline
\end{tabular}

Source: Generated by the Authors from DEA output

It can be noticed that BG Group with least total input has the least total deviations from efficiency in terms of figures while Shell who has the highest input cost appears to have highest figure of deviation from efficiency. The pattern is such that, the more the cost of input, the higher the deviations from efficiency in terms of raw figures as well as when expressed as percentages.

\subsection{Ranking of Companies based on Performance Indices}

One of the easiest methods that reveal the performance of a company in relation to industry is by computing indices so that a benchmark can be set by the best PI. The companies in the sample are ranked based on PI and listed on the following table in order of their performance.

Table 4.6

\begin{tabular}{|l|c|c|}
\hline \multicolumn{3}{|c|}{ RANKING OF COMPANIES BASED ON PERFORMANCE INDICES } \\
\hline COMPANY & RANK & AVERAGE PI \\
\hline CNOOC & 1 & 0.953811124 \\
\hline STATOIL & 2 & 0.90320202 \\
\hline CHEVRON & 3 & 0.824288901 \\
\hline CONOCOPHILIPS & 4 & 0.320441318 \\
\hline TOTAL & 5 & 0.308494184 \\
\hline EXXON MOBIL & 6 & 0.244262287 \\
\hline ENI & 7 & 0.212304417 \\
\hline SHELL & 8 & 0.181325405 \\
\hline BRITISH PETROLEUM & 9 & 0.167161818 \\
\hline SOUICE: Generated by the Auth & 10 & 0.085779072 \\
\hline
\end{tabular}

Source: Generated by the Authors from DEA output

British Petroleum (BP) ranked last with PI of 0.08 , the reason for that could be as a result of heavy loss sustained in 2010 accounting period as a result of Gulf of Mexico oil spillage which engulfed completely the profit of the year. CNOOC ranked first with PI of 0.95 followed by BG Group with index of 0.90 . One important factor to note from the DEA output is that, oil companies with low level capital base seem to perform better than those with higher capital base; it could be due to that the big companies have grown larger with difficulties in management.

An analysis into the sampled oil and gas companies' financial reports and accounts shows that few out of the sampled companies have a favourable performance index. The performance indices were computed using financial performance metrics such as ROCE, ATR, EPS and specific oil reserve ratio which is RRR. Therefore, in addition to revealing financial performance, the indices also indicate the efficiency to which the company replaces its depleted reserves which is the main yardstick for measuring the success or failure of oil and gas companies. Initial results also revealed that, oil and gas companies with lower capital base tend to perform higher than those with strong capital base.

\section{Conclusions}

Performance measurement is said to have encompasses measuring different aspects of a company, financial and non-financial, internal and external. Thus, the measurement reveals areas that need to be managed. It can now be concluded that performance measurement and performance management are two interrelated concepts that cannot be separated. The case studies examined also show that, although most individual companies have unfavourable performance over the period covered (i.e. 2009, 2010 and 2011) but the overall sampled companies' performance (on average) is little above the threshold as such a sign of relatively fair performance.

The paper also discovers that for performance management system to be effective, there should be alignment of the system and organizational objectives and that, the alignment should extend to shareholdersmanagement goals. Thus, conflict of interest between principal (shareholders) and the agents (management) undermines the performance of these companies. Consequently, lack of diversification culture poses more risk to overall performance of oil and gas companies and is one of the factors responsible for non-performance of players in the industry. 


\section{References}

[1]. Pock, T., Westlund, A., \& Fahrni, F, Gaining bilateral benefit through holistic performance management and reporting. Total Quality Management Journal , 15 (5-6), 2004, 557-567.

[2]. Santos, M. F., Lucianetti, L., \& Bourne, M, Contemporary performance measurement systems: a review of their consequences and a framework for research. Management Accounting Research Journal , 23, 2012, 79-119.

[3]. Anthes, G. H, Balanced Scorecard. Computer World Journal , 37 (7), 2003, 34

[4]. Wright, C., \& Gallun, R. A, (2008). Fundamentals of Oil and Gas Accounting (5th ed. PennWell. 2008).

[5]. Crane, L. M. (2007, July 19). Measuring Financial Performance: A Critical Key to Managing Risk. Retrieved July 23, 2012, from https://www.msu.edu/user/steind/financial_measures.pdf

[6]. Kriestensen, K., \& Westlund, A. H, Performance measurement and business result. Total Quality Management Journal , 15 (5-6), 2004, 719-733.

[7]. Kuwaiti, M. E, Performance measurement process: definition and ownership. International Journal of Operations \& Production Management , 24 (1), 2004, 55-78.

[8]. Gomes, C. F., Yasin, M. M., \& Lisboa, J. V, Performance measurement practices in manufacturing firms revisited. International Journal of Operations \& Production Management , 31 (1), 2011, 5-30.

[9]. Bala, K., \& Cook, W. D, Performance measurement with classification information: an enhanced additive DEA model. International Journal of Management Science, 31, 2003, 439-450.

[10]. Dervitsiotis, K. N, The design of performance measurement systems for management learning. Total Quality Management Journal , 15 (4), 2004, 457-473.

[11]. Neely, A., Gregory, M., \& Platts, K, Performance measurement system design: a literature review and research agenda. International Journal of Operations \& Production Management , 25 (12), 2005, 12281263.

[12]. Pavlov, A., \& Bourne, M, Explaining the effects of performance measurement on performance: an organizational routines perspectives. International Journal of Operations and Production Management , 31 (1), 2011, 101-122.

[13]. Wolf, C, Does ownership matter? The performance nd efficiency of state oil vs. private oil (1987-2006). Energy Policy Journal , 37, 2009, 2642-2652.

[14]. Ahmad, S. S. and Kouhy, R, Government Ownership and Cost Efficiency of Upstream oil and Gas Companies in Nigeria, International Journal of Energy and Statistics, 2 (4), 2014, 227-245.

[15]. Ahmad, S. S, Accounting Disclosure Practice by Oil and Gas Companies: An Analytical Review, Readings in Management Studies, 4, 2012, 182-195.

[16]. IPIECA. (2012). IPIECA. Retrieved August 12, 2012, from http://www.ipieca.org/membership

[17]. Ittner, C. D., Larcker, D. F., \& Randall, T, Performance implication of strategic performance measurement in financial services firms. Accounting, Organization and Society Journal , 28, 2003, 715741.

[18]. Avkiran, N. K, Association of DEA super-efficiency estimates with financial ratios: investigating the case for chinese banks. Omega , 39, 2011, 323-334.

[19]. Cooper, W. W., Seiford, L. M., \& Tone, K. (2007). Data envelopment analysis (2nd ed. New York: Springer). 